\title{
Article 21. Awareness-Raising
}

Each Party shall take measures to raise awareness of the importance of genetic resources and traditional knowledge associated with genetic resources, and related access and benefit-sharing issues. Such measures may include, inter alia:

(a) Promotion of this Protocol, including its objective;

(b) Organization of meetings of indigenous and local communities and relevant stakeholders;

(c) Establishment and maintenance of a help desk for indigenous and local communities and relevant stakeholders;

(d) Information dissemination through a national clearing-house;

(e) Promotion of voluntary codes of conduct, guidelines and best practices and/or standards in consultation with indigenous and local communities and relevant stakeholders;

(f) Promotion of, as appropriate, domestic, regional and international exchanges of experience;

(g) Education and training of users and providers of genetic resources and traditional knowledge associated with genetic resources about their access and benefit-sharing obligations;

(h) Involvement of indigenous and local communities and relevant stakeholders in the implementation of this Protocol; and

(i) Awareness-raising of community protocols and procedures of indigenous and local communities.

\section{Overview}

Article 21 includes a clear and unconditional obligation for Parties to raise awareness about the Protocol and ABs issues, providing an indicative list of activities $^{1}$ that can be undertaken to fulfill this obligation. The importance of awareness-raising in the ABS context and its contribution to the functioning of the Protocol should not be underestimated. ABs is still a little-known issue to the general public, as well as to the numerous government and stakeholder

1 Tsioumani, “Access and Benefit Sharing: The Nagoya Protocol," op. cit., 293.

(C) Elisa Morgera, Elsa Tsioumani, and Matthias Buck, 2015.

This is an open access chapter distributed under the terms of the Creative Commons Attribution-Noncommercial 3.0 Unported (CC-BY-NC 3.0) License. 
sectors that will be affected by the Protocol. Thus, the preamble indicates that Parties

recogniz $[\mathrm{e}]$ that public awareness of the economic value of ecosystems and biodiversity and the fair and equitable sharing of this economic value with the custodians of biodiversity are key incentives for the conservation of biological diversity and the sustainable use of its components. ${ }^{2}$

Article 21 builds upon the obligations found in the CBD on communication, education and public awareness ${ }^{3}$ and exchange of information. ${ }^{4}$ In the light of the importance of awareness-raising activities for the effective implementation of the Protocol, the Intergovernmental Committee preparing the ground for the Protocol's entry into force has already discussed the need to develop an awareness-raising strategy. 5

As Article 21 does no raise particular interpretative difficulties, the following sections will first discuss the specific relevance of this provision for the implementation of the Protocol provisions related to indigenous and local communities, and then offer final observations on the linkages between Article 21 and other provisions of the Protocol.

\section{Specific Relevance for Indigenous and Local Communities}

It should be emphasized that the non-exhaustive list of awareness-raising activities pays particular attention to the implementation challenges raised

2 Nagoya Protocol 6th preambular recital.

3 свр Article 13. See Glowka, Burhenne-Guilmin and Synge, Guide to the Convention on Biological Diversity, op. cit., 68-70; and "Programme of Work for the Global Initiative on Communication, Education and Public Awareness (CEPA)" in СвD Decision 6/19, "Communication, education and public awareness" (22 May 2002) Un Doc UNEP/CbD/ COP $/ 6 / 20$, Annex.

4 СвD Article 17. See Glowka, Burhenne-Guilmin and Synge, Guide to the Convention on Biological Diversity, op. cit., 92-93; and Greiber et al., Explanatory Guide, op. cit., 200.

5 ICNP Recommendation 1/3, "Measures to raise awareness of the importance of genetic resources and associated traditional knowledge and access and benefit-sharing related issues" in "Report of the first meeting of the Open-Ended Ad Hoc Intergovernmental Committee for the Nagoya Protocol on Access to Genetic Resources and the Fair and Equitable Sharing of Benefits Arising from their Utilization" (21 July 2011) UN Doc UNEP/CBD/ICNP/1/8, Annex; and Recommendation 2/6, "Measures to raise awareness of the importance of the genetic resources and associated traditional knowledge, and related access and benefit-sharing issues" in ICNP, "Report of the second meeting," UnEP/CBD/COP/11/6, Annex. 
by the Protocol with regards to the role of indigenous and local communities. That is, several of the activities listed under Article 21 concern raising these communities' awareness about their rights under the Protocol and their role in its implementation, and aim at addressing information asymmetries between users and community representatives negotiating MAт. ${ }^{6}$ Ultimately, Article 21 may contribute to legal empowerment of indigenous and local communities, ${ }^{7}$ by enhancing their ability to use legal tools to tackle power asymmetries and exercise greater control over decisions and processes that affect their lives and rights. 8

In addition, several of the activities listed under Article 21 aim to raise the awareness of relevant government actors and other stakeholders as to their obligations vis-à-vis indigenous and local communities under the Protocol, such as through the organization of meetings of these communities and other stakeholders and the creation of a help desk. These awareness-raising activities can be part of the mechanisms required by the Nagoya Protocol to inform potential users of traditional knowledge associated with genetic resources about their obligations. ${ }^{9}$ These activities may also contribute to Parties' efforts in supporting indigenous and local communities' development of community protocols, minimum requirements for MAT and model contractual clauses. ${ }^{10}$ In all these cases, Parties are to act with the effective participation of the indigenous and local communities concerned, ${ }^{11}$ taking into consideration their customary laws, protocols and procedures ${ }^{12}$ and being mindful of relevant international human rights norms. ${ }^{13}$

Article 21 is linked explicitly and implicitly to other provisions in the Protocol. The inclusion among the list of awareness-raising activities of the promotion

6 Greiber et al., Explanatory Guide, op. cit., 202.

7 Munyi and Jonas, “Implementing the Nagoya Protocol," op. cit., 234-235.

8 Lorenzo Cotula and Paul Mathieu, eds., Legal Empowerment in Practice, Using Legal Tools to Secure Land Rights in Africa (London: International Institute for Environment and Development, 2008).

9 Nagoya Protocol Article 12(2). See Greiber et al., Explanatory Guide, op. cit., 201. See this commentary on Article 12, section 3.

$10 \quad$ Nagoya Protocol Article 12(3). See this commentary on Article 12, section 4.

11 UNDRIP Articles 19 and 32(2); ILO Convention No. 169, Article 6(2); and fn. 54 in this commentary on Article 5.

12 Nagoya Protocol Article 12(1). See this commentary on Article 12, section 2.

13 See Introduction to this commentary, section 4. 
of the 'objective' of the Protocol implies the need to raise awareness about how ABS transactions contribute to fairness and equity between and within States, ${ }^{14}$ as well as to biodiversity conservation and sustainable use. ${ }^{15}$

Article 21 is also linked to the promotion of voluntary instruments in consultation with indigenous and local communities and relevant ABs stakeholders, ${ }^{16}$ and its implementation will be influenced by the implementation of capacitybuilding activities. ${ }^{17}$ Finally, the ABs Clearinghouse can help in promoting domestic, regional and international exchanges of awareness-raising experiences and in delivering education and training of users and providers. ${ }^{18}$

\footnotetext{
14 See this commentary on Article 1, sections 1-2.

15 See this commentary on Article 1, section 4; Article 5, section 4; Article 8, section 2; Article 9, section 2; Article 10, section 4; and Article 12, section 5.

16 See this commentary on Article 20.

17 See this commentary on Article 22.

18 Young, “An International Cooperation Perspective," op. cit., 472-473. See this commentary on Article 14, section 3.
} 